\title{
Authentic Compliance with a Symbolic Legal Standard? How Critical Race Theory Can Change Institutionalist Studies on Diversity in the Workplace
}

\author{
Yael Plitmann
}

Alexandra Kalev, Frank Dobbin, and Erin Kelly. "Best Practices or Best Guesses? Assessing the Efficacy of Corporate Affirmative Action and Diversity Policies." American Sociological Review 71 (2006): 589-617.

Lauren B. Edelman, Sally Riggs Fuller, and Iona Mara-Drita. "Diversity Rhetoric and the Managerialization of Law," American Journal of Sociology 106, no. 6 (2001): 1589-1641.

This review essay introduces critical race theory to the organizational analysis of diversity in the workplace. One central finding of the empirical institutionalist literature examining diversity in organizations is the apparent failure of diversity, as a value adopted by the organization, to transform practices of discrimination and exclusion in the workplace. Scholars in this field implicitly accept the narrative about diversity as a substantive civil rights value, associating its presence with racial justice ideals. A critical analysis of this legal concept inspired by the lessons of critical race theory highlights the problematic legal construction of diversity and its role in justifying and reinforcing racial hierarchies. Adding to existing neo-institutionalist literature, I suggest that, alongside an investigation into employers' compliance practices with diversity precepts, attention should be paid to the limitations inherent in the legal standard of diversity itself.

[T] he concept of diversity, far from a viable means of ensuring affirmative action ... is a serious distraction in the ongoing efforts to achieve racial justice.

The turn to diversity in organizations has gained significant attention in both critical race theory and empirical sociological research of organizations. In this review essay, I bring these two bodies of scholarship into conversation, illustrating how critical race theory can refocus institutionalist studies on diversity in the workplace. Grounded in different disciplines and epistemological traditions, these schools seem to share little in common. Critical race theorists have been skeptical of quantitative empirical research,

Yael Plitmann is a PhD Candidate, Jurisprudence and Social Policy Program, University of California, Berkeley, United States. E-mail: yaelplitmann@berkeley.edu

I am grateful for the invaluable feedback on previous drafts provided by Lauren Edelman, Calvin Morrill, Russell Robinson, Yan Fang, Diana Reddy, and Ntokozo Bhembe. The critique presented here is my own and does not necessarily represent the opinions of my generous commentators. 
the main method employed by organizational theorists, rejecting it for both its troubling historical origins and its reduction of race to a measurable variable (Bonilla-Silva and Zuberi 2008; Carbado 2011; Carbado and Roithmayr 2014). Critical scholars employ, instead, vastly different methods such as storytelling and textual analysis, aimed at challenging and destabilizing mainstream narratives about our legal and social worlds (Matsuda 1987; Abrams 1991; Haney López 2017). Nonetheless, it is my contention that organizational sociologists studying legal values in the workplace stand to benefit from a critical race theory analysis of those values, in both their theoretical framework and the interpretation of their findings. Facilitating a dialog between critical race theory and social science research can enrich both, allowing scholars to better understand racial discrimination in the United States (Obasogie 2013; Edelman, Smyth, and Rahim 2016). Such a conversation can be especially fruitful when it comes to examining diversity as scholars in both fields share a suspicion that diversity is not the core of the solution for organizational inequality. The scarcity of dialog among them, then, might have more to do with disciplinary barriers than substantive disagreement.

Crossing these disciplinary lines, I will focus on a prominent strand in the institutionalist literature, one concerned with the observed failure of diversity, as a legal value adopted by organizations to change the racial composition of the workplace. This line of empirical research, I suggest, treats the legal standard of diversity as a substantive social justice value a priori, even if it is an ineffective one a posteriori. Researchers in the field do not question the limitations of the legal concept itself, taking for granted that it was meant to promote workplace equality. Two classic institutionalist accounts offer explanations for the failure of diversity initiatives to advance racial justice in the workplace. Alexandra Kalev, Frank Dobbin, and others have argued that corporate policy makers seek out diversity sincerely but have no idea which initiatives are effective. Employers' compliance practices, according to this account, are genuine but clueless (Kalev, Dobbin, and Kelly 2006; Dobbin, Kim, and Kalev 2011; Dobbin and Kalev 2017). I will refer to this body of scholarship as empirical institutionalism. Lauren Edelman and various colleagues see different factors at play. They criticize the notion of diversity in the organizational, albeit not the legal, context and suggest that employers' diversity practices and rhetoric disassociate the concept from civil rights values. According to this more critical account, organizational compliance practices with diversity edicts are mostly symbolic (Edelman, Riggs Fuller, and Mara-Drita 2001; Edelman et al. 2011; Edelman 2016; Edelman, Smyth, and Rahim 2016). I will refer to this body of scholarship as critical institutionalism. Both accounts curiously leave the problematic legal concept of diversity unscathed.

A critical analysis of the legal vision of diversity, inspired by the lessons of critical race theory, exposes the limitations of the concept in addressing systematic past and ongoing racial harms. Although the concept was developed by the US Supreme Court primarily in the field of education, this legal vision was widely accepted in both the education and employment fields (Leong 2013). Diffused, ahistorical and decontextualized, diversity was constructed in the Supreme Court's affirmative action jurisprudence as an individualistic value, unconcerned with entrenched structures of racial hierarchies that are hardwired into organizational fields. As critical race theorists have argued, by diverting attention away from a repudiation of racial oppression to a symbolic commitment to tolerance for a variety of cultures and backgrounds, diversity works to obscure racism and structural inequalities while reinforcing stereotypes (Lawrence 2001; 
Ford 2002, 2005; Bell 2003; Roithmayr 2004; Bell and Hartmann 2007; Hutchison 2008; Nunn 2008; Leong 2013; Berrey 2015; Smith and Mayorga-Gallo 2017). Introducing the critique of diversity to this line of organizational research is a step toward understanding not only the self-evident failure of diversity practices in altering the racial composition of the workplace but also how they work to produce and reinforce inequality in American organizations. This critique can explain the tenacity of racial inequality in organizations not only despite, but also in relation to, costly diversity programs and ubiquitous diversity training.

This review essay adds to the neo-institutionalist literature on workplace inequality by suggesting that the inability of diversity to battle inequality lies not only with its practical implementation but also, first and foremost, with its theoretical legal construction. While institutionalists implicitly treat the concept of diversity as a substantive civil rights value hollowed out by organizational practices, the critical inquiry into diversity exposes it as a legal strategy that undermines and mystifies the possibility of racial equality in American organizations. Rather than an instance of "symbolic compliance" with civil rights values adopted by organizations to win legitimacy (Edelman and Suchman 1997; Edelman and Petterson 1999; Edelman 2016), the case of diversity is better described as authentic organizational compliance with a symbolic legal standard that, by its very definition, cannot deliver racial equality. Even when organizational diversity programs are taken seriously and executed sincerely, they cannot bring about racial equality in the workplace. This is not because "diversity programs fail," as empirical institutionalists conclude, but, rather, because they succeed. The legal concept of diversity in the American workplace works as expected according to its demarcated legal scope. Without the critical legal analysis of this concept, in other words, organizational theory on workplace inequality would not be able to fully explain why commitment to diversity in the workplace fails to change what it seems legally meant to preserve.

To make the case for these claims, I will proceed as follows: First, I will introduce the principal institutionalist studies on diversity, focusing on the work of Dobbin and Kalev as well as Edelman and her various colleagues. I will point out the institutionalists' main oversight - their uncritical stance toward the legal concept of diversity. Then, I will describe the legal construction of the notion of diversity in the contiguous educational field and its analysis by critical race scholars and other critical scholars. These sections will specifically address the two main shortcomings of diversity that render it a symbolic legal standard. I will conclude by suggesting how critical race theory can change institutionalist studies on diversity in the workplace.

\section{INSTITUTIONALIST STUDIES ON DIVERSITY IN ORGANIZATIONS}

An abundance of empirical organizational studies, the most notable of which are surveyed below, suggest that diversity programs and trainings do not change the racial composition of the American workplace (Kalev, Dobbin, and Kelly 2006; Dobbin and Kalev 2017). Examining hundreds of employment organizations across time, this body of research concluded that diversity practices largely have no effect on the racial demographics of the workplace and its management (Dobbin and Kalev 2018); that 
diversity training and diversity evaluations "are least effective" at increasing the share of black employees in management (Kalev, Dobbin, and Kelly 2006); and that diversity training "does not reduce bias, alter behavior or change the workplace" (Dobbin and Kalev 2018, 49; see also Dobbin and Kalev 2007; Dobbin, Kalev, and Kelly 2007). "Overall, it appears that diversity programs do most for white women," institutionalists conclude, while African Americans reap less benefits (Kalev, Dobbin, and Kelly 2006, 604; for an overview of these studies, see Leslie 2019; Nishii et al. 2018). Diversity training also appears to have no demonstrable effect on the careers of racial minorities in federal agencies (Naff and Kellough 2003). Even studies arguing that organizational diversity education is effective do not claim that it alters the racial composition of the workplace. Their conclusions are restricted to the modest claim that those interventions are successful in improving "knowledge about diversity and overall attitudes toward diversity" (Kulik and Roberson 2008a, 314) and in helping employees work effectively in diverse organizations (Bendick, Egan, and Lofhjelm 2001; Kulik and Roberson 2008b).

While some diversity practices have been shown to simply be ineffective, others have been found to have negative effects on the representation of African Americans in the workplace (Kalev, Dobbin, and Kelly 2006). More specifically, Kalev, Dobbin, and Erin Kelly found that "diversity trainings" are followed by an average 7 percent decline in the odds that managers are black women and that "diversity evaluations" are followed by an average 8 percent decline in the odds that managers are black men (604). Over a period of five years, companies that make diversity training mandatory for managers witnessed an average 10 percent decrease in the number of black women in management (Dobbin and Kalev 2017, 816; compare King et al. 2012). Diversity report cards, similarly, show only negative effects for African Americans as well as white women (Dobbin and Kalev 2017, 821). Kalev, Dobbin, and Kelly (2006) argue that their models allow for causal inferences about the effects of diversity practices on workplace composition, not merely associations.

Which efforts toward a racially diverse workplace do work? "Some of the most effective solutions," Dobbin and Kalev $(2016,54)$ admit, "aren't even designed with diversity in mind." Studies show, for instance, that mentoring has positive effects on the representation of white women and, to a lesser extent, on "minorities" in management (Kalev, Dobbin, and Kelly 2006, 604; Dobbin and Kalev 2018, 52). Special college recruitment programs as well as "skill and management training with special nomination procedures for underrepresented groups" were also shown to be effective (Dobbin and Kalev 2017, 818). Policies that prompt "social accountability," such as "equal opportunity" taskforces and "affirmative action managers" who are charged with overseeing the hiring and promotion of employees from underrepresented groups, were also shown to be effective, probably because of "evaluation apprehension" (Dobbin, Schrage, and Kalev 2015; see also Richard, Roh, and Pieper 2013). For the same reason, regulatory oversight of federal contractors yielded positive results throughout the years in which the Department of Labor conducted compliance reviews. Once enforcement was reduced during the Reagan administration and onwards, positive diversity metrics declined as well (Kalev, Dobbin, and Kelly 2006; Dobbin and Kalev 2017).

Empirical institutionalists have suggested several explanations for the failure of most diversity initiatives in the workplace. Dobbin and Kalev $(2017,2018)$ postulate that short-term educational interventions, such as diversity training, cannot change 
biases that workers have learned over a lifetime. They further posit that emphasizing the legal aspects of diversity works to its detriment - not because they see the legal concept as flawed - the claim I am making - but, rather, because legality "may lead employees to think that commitment to diversity is being coerced," causing a backlash (Dobbin and Kalev 2018, 51). Critical institutionalists, on the other hand, criticize organizational perceptions of diversity as overly inclusive and, thus, ineffective at promoting civil rights values (Edelman, Riggs Fuller, and Mara-Drita 2001). They nonetheless stop short of critiquing the legal concept itself, although its idea of diversity was overly inclusive from the outset. For critical institutionalists, diversity programs are an instance of "window dressing," a practice adopted by employers to protect themselves against liability without transforming the racial composition of their organization (Edelman, Riggs Fuller, and Mara-Drita 2001; Edelman 2016, 149, 156-57; Edelman, Smyth, and Rahim 2016; Edelman et al. 2011). In their well-known 2006 piece, Kalev, Dobbin, and Kelly $(2006,610)$ also entertain this idea as a possible explanation for the perceived failures of diversity programs. A decade later, however, Dobbin and Kalev $(2017,812)$ have suggested that "employers could not have deliberately adopted ineffective diversity practices because they knew not which were effective." Diversity initiatives fail, according to this recent account, because the diversity innovations that are ultimately adopted are not necessarily the most effective ones, and their adoption is not based on empirical evidence (814).

Essentially placing the blame for diversity's failures on behaviors and attitudes of employers, the neo-institutionalist literature largely ignores the problematics of the legal concept of diversity itself. Critical of organizational actors, this approach does not extend the same exacting critique to the legal environment in which these actors operate. Responding to this oversight, I proceed to describe this legal environment.

\section{THE LEGAL VISION OF DIVERSITY AND ITS CRITIQUE}

Theories of law and organizations suggest that organizations are responsive to their legal environment and adopt different normative practices and structures responding to widely accepted legal ideas (Edelman 1990). Diversity is such an idea. Around 75 percent of corporate diversity programs, for example, cover legal content as part of the training (Dobbin and Kalev 2018). This does not mean, to be sure, that legal notions that become institutionalized in organizational fields necessarily directly track the law. Rather, these notions are influenced and shaped by the law as well as by the organizational fields in which they circulate. I now turn to a brief description of the notion of diversity as constructed by law and its critique.

Constitutional law scholars usually cite Justice Lewis Powell's plurality opinion in the 1978 case Regents of the University of California v. Bakke as the first recognition by the US Supreme Court of the benefits of diversity in educational organizations (Post 2003; Crocker 2007; Leong 2013). ${ }^{1}$ In the Bakke case, the Supreme Court struck down the use of quotas by University of California Davis Medical School, applying the constitutional standards of "strict scrutiny" to the university's consideration of race in admissions. Although the majority opinion written by Justice Powell declared racial

1. Regents of the University of California v. Bakke, 438 U.S. 265 (1978). 
quotas a violation of the 14th Amendment, it nonetheless allowed for the consideration of race under the rationale of "diversity" as a "compelling state interest." Important for our purposes is Powell's holding that neither a remedial justification nor the imperative to correct societal discrimination are compelling governmental interests that allow for race-conscious affirmative action in admissions. Instead, Powell championed "ethnic diversity" meant to ensure that universities could "select those students who will contribute the most to the "robust exchange of ideas" as the sole rationale for affirmative action policies. He further emphasized that this consideration is "only one element in a range of factors a university properly may consider in attaining the goal of a heterogeneous student body."

Despite the widely acknowledged incoherence of the Bakke decision (Chin 1996), its conceptualization of diversity in education was reaffirmed and extended by the US Supreme Court in later decades. In Grutter v. Bollinger and Gratz v. Bollinger, the Supreme Court reiterated the distinction between restitution justifications and the diversity rationale, citing the latter as the sole reasoning for race-based university admission policies. ${ }^{3}$ Justice Sandra Day O'Connor, writing for the court, endorsed Justice Powell's position that "reducing the historic deficit of traditionally disfavored minorities ... [is] an unlawful interest in racial balancing." 4 Similarly, "an interest in remedying societal discrimination" was also rejected since "such measures would risk placing unnecessary burdens on innocent third parties "who bear no responsibility for whatever harm the beneficiaries of the special admissions program are thought to have suffered'." Again, the only public interest deemed sufficiently compelling to pass the mandates of the constitutional test of strict scrutiny was the interest in a diverse student body and only if that interest did not consider race alone. Racial diversity was presented on par with other diverse personality traits that one may come to possess, as O'Connor stated: "Just as growing up in a particular region or having particular professional experience is likely to affect an individual's views, so too is one's own, unique, experience of being a racial minority in a society, like our own, in which race unfortunately still matters." ${ }^{\prime 6}$

More recently, in Parents Involved in Community Schools v. Seattle, the US Supreme Court struck down school assignment plans that considered race to assign students to oversubscribed public schools. ${ }^{7}$ Determining that de jure segregation was no longer present, the court rejected the interest in remedying harms traceable to segregation as a compelling state interest that could pass the strict scrutiny test. Any continued use of race-based school assignments, the court reasoned, must be justified on some other basis, such as diversity. That legal concept, as Chief Justice John Roberts reiterated, cannot account only for race:

[T] he diversity interest [accepted in Grutter] was not focused on race alone but encompassed all factors that may contribute to student body diversity ... [including] admittees who have lived or traveled widely abroad, are fluent in several languages, have overcome personal adversity and family hardship,

2. Bakke, 306-7, 313-14.

3. Grutter v. Bollinger, 539 U.S. 306 (2003); Gratz v. Bollinger, 539 U.S. 244 (2003).

4. Bakke, 438 U.S., 323.

5. Bakke, 438 U.S., 324.

6. Bakke, 438 U.S., 333.

7. Parents Involved in Community Schools v. Seattle School Dist. No. 1, 551 U.S. 701 (2007). 
have exceptional records of extensive community service, and have had successful careers in other fields. ${ }^{8}$

Race-conscious practices were similarly rejected by the Supreme Court in employment discrimination cases, even though the diversity rationale was never directly addressed there. Presented with challenges to affirmative action in the workplace, for example, the court allowed employers to consider race only to address discrimination in their particular organization, not to remedy historical injustices more generally. ${ }^{9}$ Meanwhile outside the court, the legal vision of diversity as designed in Bakke gained wide acceptance in the business community, and actors in both educational and employment organizations today invoke diversity as the main rationale for their race conscious policies (Edelman, Riggs Fuller, and Mara-Drita 2001; Wilkins 2004; Leong 2013; Nakamura and Edelman 2019).

This remarkable legal reconfiguration of affirmative action from a policy meant to tackle the historical injustices of race-based exclusions to one aimed at achieving some unspecified degree of "diversity" that benefits "all" is evident in diversity practices across organizational fields. Curiously, critical institutionalists writing on diversity in organizations nonetheless ascribe the problematic version of diversity to its organizational, rather than legal, design. Edelman, Sally Riggs Fuller, and Iona Mara-Drita (2001, 1591,1627 ) agree that the organizational diversity rhetoric had "some roots" in judicial doctrine, but they portray diversity practices applied by organizations as a transfiguration of the legal ideal of diversity. Criticizing the dissociation of diversity from civil rights values in the organizational field, they argue that "[managerial] diversity rhetoric replaced the legal vision of diversity, which is grounded in moral efforts to right historical wrongs" (1626; see also 1632). Similarly, Edelman $(2016,149)$ describes the corporate discourse on diversity as "perhaps the most powerful form of managerialization [of law] that has occurred." And Edelman, Aaron Smyth, and Asad Rahim (2016, 408) posit that "managerial rhetoric reframes affirmative action and antidiscrimination policies as diversity management" (see also Edelman et al. 2011; Nakamura and Edelman 2019).

It is my contention, conversely, that legal rhetoric of US Supreme Court justices initially divorced diversity from civil rights, antidiscrimination values, and affirmative action rationales. To be sure, processes of managerialization and other occurrences in the organizational arena obviously affect diversity practices. But it is not only its application within organizations that reframed antidiscrimination values as "diversity management." Affirmative action jurisprudence was originally responsible for that. Organizational actors who implement this legal ideal may do so authentically or ceremonially, but diversity's failings cannot be ascribed to their hypocrisy or incompetence alone. Relying on critical race scholarship, I suggest that there never existed a "legal vision of diversity, which is grounded in moral efforts to right historical wrongs" (Edelman, Riggs Fuller, and Mara-Drita 2001, 1626).

8. Parents Involved, 551 U.S., 2753 (internal quotation marks omitted).

9. Wygant v. Jackson Board of Education, 476 U.S. 267, 277 (1986); City of Richmond v. J.A. Croson Company, 488 U.S. 469, 493-94 (1989); Adarand Constructors, Inc. v. Pena, 515 U.S. 200, $220-21$ (1995). 
It was not business corporations but, rather, the US Supreme Court in Bakke that was the first to explicitly reject grounding racial diversity in a public interest in "reducing the historic deficit of traditionally disfavored minorities," as an unlawful attempt at racial balancing. ${ }^{10}$ The consideration of race was allowed in order to advance only one interest - "the attainment of a diverse student body" — defined as "ethnic diversity" whose impetus, as we will see, is institutional and professional success, not racial justice causes. ${ }^{11}$ This framing, exacerbated and entrenched in judicial precedents since 1978, refutes the notion that diversity was ever meant to address historical wrongs or current racial injustices. Rather, it codified diversity as an individualistic concept, one grounded in a nonstructural, ahistorical approach to social ills that emphasizes nonracial aspects of institutional diversity at the expense of a meaningful consideration of structurally created identities, such as race. This is the diversity ethos and rhetoric in which workplace organizations are steeped.

Main themes within critical race literature expose this legal version of diversity as a symbolic value with inherent limitations. Paying attention to this literature can lead sociological research on diversity to (1) better understand the diversity rationale and its scope in order to adopt a more accurate definition of diversity as an empirical object of observation and measurement and (2) distinguish diversity from equality, making the theoretical framework of their studies more precise. I will turn now to these objectives.

\section{THE SCOPE OF DIVERSITY}

Empirical institutionalist studies on the effectiveness of diversity practices in organizations take for granted that the diversity ideal was designed to alter the racial composition of organizations. This implicit assumption is the basis for their research design, which ties the presence of a "diversity program," as an independent variable, with a dependent variable, such as the odds of increasing the share of black Americans in management (Kalev, Dobbin, and Kelly 2006; Dobbin and Kalev 2016, 2017, 2018). But the legal concept of diversity was never designed to revise the racial makeup of institutions. It is neither confined to, nor does it require, a consideration of race or other legally protected status.

Critical institutionalist writings on diversity initiatives that adopt a more suspicious approach make this point clear. Edelman, Riggs Fuller, and Mara-Drita (2001, 1590) have found that corporate rhetoric frames the concept of diversity to include "diversity of thought, lifestyle, culture, dress, and numerous other attributes," which "appear on a par with diversity of sex and race." They point out, moreover, that over 10 percent of the managerial articles they examined "offered a construction of diversity that explicitly mentioned inclusion of or attention to whites and males" (1617). Executives of Fortune 1000 companies tend to exclude race and gender from their definition of diversity altogether (Embrick 2011), and samples of white Americans understand diversity in race-neutral ways too (Bell and Hartmann 2007). Even in federal agencies, diversity programs focus on a variety of diverse elements, such as "different 
backgrounds, customs, beliefs, religions, languages, knowledge, superstitions, values, social characteristics, etc" (Kellough and Naff 2004, 66).

Whereas critical institutionalists view this broad definition of diversity as employing "nonlegal" dimensions of difference, such as "culture, geographic location, dress style, and lifestyle" (Nakamura and Edelman 2019, 2645; Edelman, Riggs Fuller, and Mara-Drita 2001, 1606-7), I argue that these dimensions are indeed core elements of the legal view of diversity. Diversity was forged from the onset as a wide-ranging "cultural diversity," or an even broader "diversity of backgrounds," aimed at fostering a general sense of accommodation for the varying "traits" that individuals might come to possess, among which race is only one consideration. Within this scheme, the distinction between lifestyle choices and idiosyncratic traits (for example, personalities, tastes, hobbies) and structurally based identities (for example, race, gender, disability) is eroded. This diffused definition allows for an organization to boast its diversity policies without addressing racial diversity whatsoever. As one critical scholar's bitter irony suggests, even "being ideologically opposed to affirmative action could make one diverse" (Nunn 2008, 721). Legally designed in this broad way, diversity can encompass everyone and anyone and become a meaningless concept. Its invocation in a specific context does not indicate, let alone guarantee, racial diversity in the organization.

But even if a diversity plan has made explicit racial diversity as its goal (by itself an unverified supposition), it is still necessary to determine whether we are witnessing meaningful racial diversity. By evaluating diversity in employment as mere changes in the percentage of women and black workers (perhaps the only available measurement in quantitative research), empirical institutionalist studies move closer to measuring what Nancy Leong $(2013,2169)$ has termed "the 'thin' version of the diversity objective," which relies on numbers and "is exclusively concerned with improving the superficial appearance of diversity." Critical diversity studies offer a parallel critique of this approach calling it "diversity as acceptance" (Smith and Mayorga-Gallo 2017, 895). According to this concept, the presence of underrepresented groups is often equated with their integration in the workplace, despite enduring organizational inequalities. The "thick" version of diversity, on the other hand, calls for an evaluation of the workplace's racial environment, the presence of segregation within the workplace, and other measures of inequality (Leong 2013). Such an evaluation can also allow one to determine whether the implementation of the "thin" version of diversity amounts to mere tokenism. As critical race theorists have argued, where insignificant numbers of African Americans are hired and promoted, meaningful change in organizational practices regarding race discrimination will not follow. Tokenism, in fact, makes things worse. Sociologists and critical race scholars alike have suggested that tokenism makes it harder for underrepresented employees to succeed and cannot alter existing power dynamics in institutions (Kanter 1977; Nunn 2008; Carbado and Gulati 2013).

The problem with an overly inclusive concept of diversity pertains not only to the countless non-racialized diverse groups but also to groups included within the narrower scope of racial diversity. The last consideration in this section thus asks exactly which racial groups a workplace diversity initiative is geared toward. A program aimed at the inclusion of African Americans in the workplace is not the same as one concerned with the broader category of "employees of color" and "minorities" more generally. Such over-expansive racial categories can include, inter alia, Asian Americans, Indian foreign 
workers, Middle Eastern immigrants, and, arguably, even American Jews. The current and historical discriminatory employment practices experienced by these groups vary dramatically. The recurrent incidents of police killing of unarmed African Americans have proven these distinctions to be even more consequential. Responding to the public discourse on the matter, critical race theorists have recently pointed out that "'racism' fails to fully capture what black people in this country are facing. The right term is 'anti-blackness"' (Ross 2020). In this regard, the broad categories of "people of color" and "minorities" do little to address the unique and pervasive forms of oppression endured almost entirely by many African Americans in the American workplace and beyond.

Further, the empirical institutionalist studies mentioned above, although accounting for some intersectional identities (for example, black women), lump together the various black racialized groups without differentiating between black immigrants and black natives (for a critique of this approach in the education context, see Massey et al. 2007; Brown and Bell 2008). According to these metrics, a workplace in which the percentage of "black workers" in management has increased would be considered a diverse workplace even if its ranks were comprised of, for example, black Canadian visiting workers, first generation African immigrants, and only a handful of African American employees. To be sure, data distinguishing between black Americans and African immigrants in organizations may be partial or even missing, but these constraints are not acknowledged by researchers, nor do they concern corporate policy makers. Indifferent and even antagonistic to the cause of repairing racial harms perpetrated against black natives, the diversity ideal presents no separate justification for the admission and promotion of African American employees in comparison to other minority groups. All are perceived to similarly contribute to the heterogeneity of an organization.

By the same token, it is worth considering who are the African American workers eventually represented among the ranks of American organizations in the intersection of race and class (Crenshaw 1989). Derrick Bell (2003, 1632), a prominent critical race scholar, has cautioned that they are more likely to be "the children of wealth and privilege." Other critical race theorists have pointed out that black workers who fail to "perform whiteness" by behaving in ways that are consistent with what are perceived to be "white norms" are penalized in the workplace for being "too black" (Carbado and Gulati 2013). Performing whiteness can be a costly endeavor. Lauren Rivera (2012), for example, found that "cultural homogeneity," which determines who will eventually be hired by elite firms, is signaled by class markers and extracurricular activities associated with the upper-middle class. Ellen Berrey (2015) similarly found that diversity discourse allows for the "selective inclusion" of a few carefully chosen members of oppressed groups. These empirical accounts suggest that the diversity rationale may facilitate a denial of access to working-class African Americans in comparison to their affluent peers.

To summarize, the diffused legal vision of diversity, which insists on de-emphasizing race, treating it as one "personality trait" among many, did not pass over the organizational field. Because the scope of diversity is so broad, its relation to race so tenuous, and its potential for remedying past injustices principally denied, empirical institutionalists' underlying assumption that an organizational diversity program, if authentically and competently implemented, could alter the racial composition of an institution begs 
reexamining. The intersectional, intra-racial quandaries raised here problematize this assumption. The current legal vision of diversity undermines and obfuscates the possibility of racial equality in American organizations while using celebratory rhetoric that signals commitment to progressive values. It is, in that sense, the paradigmatic symbolic legal value.

\section{DIVERSITY VERSUS RACIAL EQUALITY}

The uncritical view of the legal concept of diversity in institutionalist studies becomes glaring when scholars use the diffused and unspecified ideal of "diversity" interchangeably with more robust concepts such as antidiscrimination (Dobbin and Kalev 2018, 52), integration (Kalev, Dobbin, and Kelly 2006, 611), equal opportunity (Dobbin and Kalev 2017, 811; Nakamura and Edelman 2019, 2648), civil rights (Edelman, Riggs Fuller, and Mara-Drita 2001), and the redress of inequality (Kalev, Dobbin, and Kelly 2006, 589-91, 610-12; Dobbin, Schrage, and Kalev 2015, 1014). Kalev, Dobbin, and Kelly $(2006,611)$, for instance, refer to diversity programs as practices that "address social-psychological and social-relational sources of inequality." Yet nowhere in that study, or equivalent studies, have researchers shown that diversity initiatives were meant to address the sources of inequality at all. To the contrary, critical race scholars have underscored how the legal idea of diversity excludes the meaningful remediation of inequality as part of its rationale.

Diversity, claims Derrick Bell $(2003,1622)$, is "a serious distraction in the ongoing efforts to achieve racial justice.” Not only is diversity not meant to promote racial equality, the critique goes, but it was also introduced by the US Supreme Court as a competing rationale for affirmative action precisely because it does not espouse a vision of racial equality that might threaten current racial hierarchies (Ford 2005, 52; Nunn 2008, 726). This critique holds true from a historical perspective as well. Drawing on archival materials, Asad Rahim $(2020,1424)$ recently suggested that Justice Powell's turn to diversity in Bakke "was motivated, at least in part, by a desire to deradicalize college campuses," not by a racial justice imperative.

By equating racial diversity with cultural and ethnic pluralism, Richard Ford $(2005,45)$ explains, the US Supreme Court in Bakke underscored "the innocent 'fact' of cultural difference over the politically imposed wrongs of status hierarchy." Diverting attention away from a necessary disavowal of racial oppression to a seemingly neutral plea for tolerance, diversity discourse "mangles the historical record, softens the diagnosis of social injustice and as a result prescribes a palatable placebo in place of a badly needed, if bitter, pharmaceutical" (53; see also Ford 2002). Scholars of critical diversity studies have similarly argued that "diversity ideology" "both constructs [racial] difference as natural and disavows its negative impact on the lives of those who are so constructed" (Bell and Hartmann 2007, 910; see also Andersen 1999; Embrick 2011).

In these ways, not only does diversity fail as a racial justice concept, but it also works to obscure and conceal racism, while creating an appearance of inclusivity and accommodation (Ford 2005; Bell and Hartmann 2007; Hutchison 2008). As a result, the notion of diversity has also pushed aside more radical and substantive solutions for inequality, which "focus on the need to remedy past discrimination, address 
present discriminatory practices, and reexamine traditional notions of merit" (Lawrence 2001, 931; see also Delgado 1991; Roithmayr 2004). Some of these critiques were grounded empirically. Ellen Berrey $(2015,272)$ demonstrated how diversity discourse is "a mechanism of containing and co-opting racial justice" that relieves organizations of their responsibility for inequality in their midst. And psychologists have shown in experiments how the presence of diversity structures in organizations conceals and legitimizes racist and sexist institutional practices (Kaiser et al. 2013; Brady et al. 2015).

The legal contours of diversity lead Bell $(2003,1625)$ to portray diversity objectives as, first and foremost, an interest of white Americans facing an increasingly diverse job market and global economy. The race-conscious admission policy in the Grutter case gained Justice O'Connor's vote, he suggests, only because it "minimizes the importance of race while offering maximum protection to whites" (see also Hutchison 2008). In that sense, organizational diversity efforts fit neatly with Bell's $(1980,523)$ famous "interest convergence theory," according to which "the interest of Blacks in achieving racial equality will be accommodated only when it converges with the interests of whites." Black Americans who gain access to an organization because of its diversity policy, he argues, simply happen to be "the fortuitous beneficiaries of a ruling motivated by other interests" (Bell 2003, 1625). As another critical race theorist put it, "the reason the Supreme Court found a compelling state interest in Grutter was that people of color could be used as a means to white ends" (Nunn 2008, 724; see also Fair 2004; Smith and Mayorga-Gallo 2017). This idea is closely tied to the critical notion of the commodification of race as part of the diversity discourse, a process through which nonwhiteness is assigned a market value and tokenistic racial representations are favored (Leong 2013). By focusing on the advantages that diversity creates for whites, nonwhite people are commodified and "used by whites as objects that serve to benefit, entertain, or color the lives of whites" (Smith and Mayorga-Gallo 2017, 897).

Understanding that the legal version of diversity is not tantamount to, and is largely at odds with, racial equality can produce research that is more critically theorized. Before concluding that diversity initiatives fail, empirical institutionalists should consider whether they in fact play out in the ways in which they were meant to from the start. To suggest, as empirical and critical institutionalists do, that the problem with diversity lies with the ways in which diversity initiatives are carried out in the organizational field is to miss a critical point about the limitations of this symbolic legal concept in addressing racial inequality more generally.

\section{CONCLUSION: NEO-INSTITUTIONAL THEORY MEETS CRITICAL RACE THEORY}

Empirical institutionalist studies on diversity are important quantitative analyses of organizational practices. As we have seen, however, these studies uncritically assume that the diversity ideal was designed to promote a more racially equitable workplace. When their findings show a tenuous relation between the two variables, researchers conclude that diversity programs do not work, whether because of incomplete fulfillment by employers or their inauthentic compliance with legal standards. In so doing, these studies are part of the institutionalist tradition that demonstrates how employers' 
compliance with civil rights legislation is often a facial commitment to equality and antidiscrimination in the workplace, which is symbolic or ceremonial in nature (Meyer and Rowan 1977; Dobbin et al. 1993; Sutton et al. 1994; Edelman 2016).

This line of research considers formal legal rules largely ambiguous and controversial, inviting organizational actors to concretize the law and fill in its lacunae (Edelman 2016). When organizations possess the power to construct the meaning of their compliance, processes such as the "managerialization of law" occur, in which managerial logic penetrates legal fields and, in turn, changes the meaning of law (Edelman 2016). According to critical institutionalists, this is what happened with the diversity ideal (Edelman, Riggs Fuller, and Mara-Drita 2001; Edelman, Smyth, and Rahim 2016). At the same time, however, both empirical and critical institutionalists implicitly and uncritically assume that current legal precepts regarding diversity unambiguously promote a vision of civil rights that can disrupt racial injustices in the workplace. In this account, employers' actions-insincere, symbolic, and ineffective as they are-impede law's lucid vision of justice.

Critical race theory conceptions of diversity, as I have shown, allow us to challenge the neo-institutionalists' background assumptions about the interplay of law and organizations. Rather than eradicating current racial hierarchies, the doctrinal legal development of diversity by the court reproduces and reinforces those structures further. Superficially speaking, the language of racial inclusion and the celebration of differences as well as the legal discourse on diversity reject transformative agendas meant to address past and present racial injustices, preserving the current social structure. Cast in all but colorblind terms of "diversity of backgrounds," in which race plays only a limited role, if any, the legal commitment to diversity lacks any meaningful substance capable of combating pervasive racial discrimination in the workplace. Far from an effort toward racial equality, the legal vision of diversity is an impediment to the enduring struggle for racial justice.

The critical perspectives on diversity thus complicate the institutionalist notion of law's "failures" in the workplace. Instead of understanding empirical findings about diversity in the workplace as another illustration of the "law on the books, law in action" dichotomy, critical race theory invites us to reconsider the very supposition that the legal construction of diversity was an effort toward racial equality to begin with. It raises the question of whether the case of diversity is less an example of the "managerialization of law" or of its ineffective implementation than an instance of authentic compliance and keen organizational alignment with a legal framework that does nothing to threaten the inequitable status quo of those organizations.

\section{REFERENCES}

Abrams, Kathryn. 1991. "Hearing the Call of Stories." California Law Review 79: 971-1004.

Andersen, Margaret L. 1999. "Diversity without Oppression: Race, Ethnicity, Identity and Power." In Critical Ethnicity: Countering the Waves of Identity Politics, edited by M. Kenyatta, 5-20. Lanham, MD, MD: Rowman \& Littlefield.

Bell, Derrick. 1980. "Brown v. Board of Education and the Interest-Convergence Dilemma." Harvard Law Review 93: 518-33.

—. 2003. "Diversity's Distractions." Columbia Law Review 103: 1622-33. 
Bell, Joyce M., and Douglas Hartmann. 2007. "Diversity in Everyday Discourse: The Cultural Ambiguities and Consequences of 'Happy Talk." American Sociological Review 72, no. 6: 895914.

Bendick, M., Mary L. Egan, and Suzanne M. Lofhjelm. 2001. "Workforce Diversity Training: From Anti-Discrimination Compliance to Organizational Development." Human Resource Planning 24: $10-25$.

Berrey, Ellen. 2015. The Enigma of Diversity: The Language of Race and the Limits of Racial Justice. Chicago: University of Chicago Press.

Bonilla-Silva, Eduardo, and Tukufu Zuberi. 2008. "Toward a Definition of White Logic and White Methods." In White Logic, White Methods: Racism and Methodology, edited by Tukufu Zuberi and Eduardo Bonilla-Silva, 3-30. Lanham, MD: Rowman \& Littlefield.

Brady Laura M., Cheryl R. Kaiser, Brenda Major, and Teri A. Kirby. 2015. "It's Fair for Us: Diversity Structures Cause Women to Legitimize Discrimination." Journal of Experimental Social Psychology 57: $100-10$.

Brown, Kevin, and Jeannine Bell. 2008. "Demise of the Talented Tenth: Affirmative Action and the Increasing Underrepresentation of Ascendant Blacks at Selective Higher Educational Institutions." Ohio State Law Journal 69: 1229-83.

Carbado, Devon W. 2011. "Critical What What?" Connecticut Law Review 43: 1593-1643.

Carbado, Devon W., and Mitu M. Gulati. 2013. Acting White? Rethinking Race in Post-Racial America. Oxford: Oxford University Press.

Carbado, Devon W., and Daria Roithmayr. 2014. "Critical Race Theory Meets Social Science." Annual Review of Law and Social Science 10: 149-67.

Chin, Gabriel J. 1996. "Bakke to the Wall: The Crisis of Bakkean Diversity." William and Mary Bill of Rights Journal 4: 881-947.

Crenshaw, Kimberly. 1989. "Demarginalizing the Intersection of Race and Sex: A Black Feminist Critique of Antidiscrimination Doctrine, Feminist Theory and Antiracist Politics." University of Chicago Legal Forum 1989, no. 1: 139-67.

Crocker, Thomas P. 2007. "Envisioning the Constitution." American University Law Review 57: 1-72.

Delgado, Richard. 1991. "Affirmative Action as a Majoritarian Device: Do You Really Want to Be a Role Model?" Michigan Law Review 89: 1222-31.

Dobbin, Frank, and Alexandra Kalev. 2007. "The Architecture of Inclusion: Evidence from Corporate Diversity Programs." Harvard Journal of Law and Gender 30: 279-301.

_. 2016. "Why Diversity Programs Fail: And What Works Better." Harvard Business Review (July-August): 52-60.

. 2017. "Are Diversity Programs Merely Ceremonial? Evidence-Free Institutionalization.” In The Sage Handbook of Organizational Institutionalism, edited by Roystone Greenwood, Christine Oliver, Thomas B. Lawrence, and Renate E. Meyer, 808-28. London: Sage Publications.

. 2018. "Why Doesn't Diversity Training Work? The Challenge for Industry and Academia." Anthropology Now 10, no. 2: 48-55.

Dobbin, Frank, John Sutton, John Meyer, and Richard Scott. 1993. "Equal Employment Opportunity Law and the Construction of Internal Labor Markets." American Journal of Sociology 99, no. 2: 396-427.

Dobbin, Frank, Alexandra Kalev, and Erin Kelly. 2007. "Diversity Management in Corporate America." Contexts 6: 21-28.

Dobbin, Frank, Soohan Kim, and Alexandra Kalev. 2011. "You Can't Always Get What You Need: Organizational Determinants of Diversity Programs." American Sociological Review 76, no. 3: 386411.

Dobbin, Frank, Daniel Schrage, and Alexandra Kalev. 2015. "Rage against the Iron Cage: The Varied Effects of Bureaucratic Personnel Reforms on Diversity." American Sociological Review 80, no. 5: 1014-44.

Edelman, Lauren B. 1990. "Legal Environments and Organizational Governance: The Expansion of Due Process in the Workplace." American Journal of Sociology 95, no. 6: 1401-40. . 2016. Working Law: Courts, Corporations, and Symbolic Civil Rights. Chicago: University of Chicago Press. 
Edelman, Lauren B., Linda H. Krieger, Scott R. Eliason, Catherine R. Albiston, and Virginia Mellema. 2011. "When Organizations Rule: Judicial Deference to Institutionalized Employment Structures." American Journal of Sociology 117, no. 3: 888-954.

Edelman, Lauren B., and Stephen Petterson. 1999. "Symbols and Substance in Organizational Response to Civil Rights Law." Special issue, "The Future of Affirmative Action." Research in Social Stratification and Mobility 17: 107-35.

Edelman, Lauren B., Sally Riggs Fuller, and Iona Mara-Drita. 2001. "Diversity Rhetoric and the Managerialization of Law." American Journal of Sociology 106, no. 6: 1589-1641.

Edelman Lauren B., Aaron C. Smyth, and Asad Rahim. 2016: "Legal Discrimination: Empirical Sociolegal and Critical Race Perspectives on Antidiscrimination Law." Annual Review of Law and Social Science 12: 395-415.

Edelman, Lauren B., and Mark C. Suchman. 1997. "The Legal Environments of Organizations." Annual Review of Sociology 23: 479-515.

Embrick, David G. 2011. "The Diversity Ideology in the Business World: A New Oppression for a New Age." Critical Sociology 37, no. 5: 541-56.

Fair Bryan K. 2004. "Taking Educational Caste Seriously: Why Grutter Will Help Very Little." Tulane Law Review 78: 1843-75.

Ford, Richard T. 2002. "Beyond 'Difference': A Reluctant Critique of Legal Identity Politics." In Left Legalism/Left Critique, edited by Wendy Brown and Janet Halley, 38-79. Durham, NC: Duke University Press.

2005. Racial Culture. Princeton, NJ: Princeton University Press.

Haney López, Ian. 2017. "Introduction." Race, Law and Society. London: Routledge.

Hutchison, Harry G. 2008. "Moving Forward? Diversity as a Paradox? A Critical Race View." Catholic University Law Review 57: 1059-98.

Kaiser Cheryl R., Brenda Major, Ines Jurcevic, Tessa L. Dover, Laura M. Brady, and Jenessa R. Shapiro. 2013. "Presumed Fair: Ironic Effects of Organizational Diversity Structures." Journal of Personality and Social Psychology 104, no. 3: 504-19.

Kalev, Alexandra, Frank Dobbin, and Erin Kelly. 2006. "Best Practices or Best Guesses? Assessing the Efficacy of Corporate Affirmative Action and Diversity Policies." American Sociological Review 71: 589-617.

Kanter, Rosabeth Moss. 1977. Men and Women of the Corporation. New York: Basic Books.

Kellough Edward J., and Katherine C. Naff. 2004. "Responding to a Wake-up Call: An Examination of Federal Agency Diversity Management Programs." Administration and Society 36: 62-90.

King, Eden B., Jeremy F. Dawson, David A. Kravitz, and Lisa M. V. Gulick. 2012. "A Multilevel Study of the Relationships between Diversity Training, Ethnic Discrimination and Satisfaction in Organizations." Journal of Organizational Behavior 33, no. 1: 5-20.

Kulik, Carol T., and Loriann Roberson. 2008a. "Common Goals and Golden Opportunities: Evaluations of Diversity Education in Academic and Organizational Settings." Academy of Management Learning and Education 7: 309-31.

2. 2008b. "Diversity Initiative Effectiveness: What Organizations Can (and Cannot) Expect from Diversity Recruitment, Diversity Training, and Formal Mentoring Programs." In Diversity at Work, edited by A. P. Brief, 265-317. Cambridge, UK: Cambridge University Press.

Lawrence, Charles R. III. 2001. "Two Views of the River: A Critique of the Liberal Defense of Affirmative Action." Columbia Law Review 101: 928-75.

Leong, Nancy. 2013. "Racial Capitalism." Harvard Law Review 126: 2151-2226.

Leslie, Lisa M. 2019. "Diversity Initiative Effectiveness: A Typological Theory of Unintended Consequences." Academy of Management Review 44, no. 3: 538-63.

Matsuda Mari J. 1987. "Looking to The Bottom: Critical Legal Studies and Reparations." Harvard Civil Rights-Civil Liberties Law Review 22: 323-99.

Massey, Douglas S., Margarita Mooney, Kimberly C. Torres, and Camille Z. Charles. 2007. "Black Immigrants and Black Natives Attending Selective Colleges and Universities in the United States." American Journal of Education 113: 243-71.

Meyer, John W., and Brian Rowan. 1977. "Institutionalized Organizations: Formal Structure as Myth and Ceremony." American Journal of Sociology 83, no. 2: 340-63. 
Naff, Katherine C., and Edward J. Kellough. 2003. "Ensuring Employment Equity: Are Federal Diversity Programs Making a Difference?" International Journal of Public Administration 26: 1307-36.

Nakamura, Brent K., and Lauren B. Edelman. 2019. "Bakke at 40: How Diversity Matters in the Employment Context." University of California Davis Law Review 52, no. 5: 2627-80.

Nishii, Lisa H., Jasmien Khattab, Meir Shemla, and Rebecca M. Paluch. 2018. "A Multilevel Process Model for Understanding Diversity Practice Effectiveness." Academy of Management Annals 12, no. 1: 37-82.

Nunn, Kenneth B. 2008. "Diversity as a Dead-End." Pepperdine Law Review 705, no. 35: 705-32.

Obasogie, Osagie K. 2013 "Foreword: Critical Race Theory and Empirical Methods." University of California Irvine Law Review 3: 183-86.

Post, Robert C. 2003. "Foreword: Fashioning the Legal Constitution: Culture, Courts, and Law." Harvard Law Review 117, no. 4: 4-112.

Rahim, Asad. 2020. "Diversity to Deradicalize." California Law Review 108, no. 5: 1423-86.

Richard, Orlando C., Hyuntak Roh, and Jenna R. Pieper. 2013. "The Link between Diversity and Equality Management Practice Bundles and Racial Diversity in the Managerial Ranks: Does Firm Size Matter?" Human Resource Management 52, no. 2: 215-42.

Rivera, Lauren A. 2012. "Hiring as Cultural Matching: The Case of Elite Professional Service Firms." American Sociological Review 77, no. 6: 999-1022.

Roithmayr, Daria. 2004. "Tacking Left: A Radical Critique of Grutter." Constitutional Commentary 21: 191-220.

Ross, Kihana M. 2020. "Call It What It Is: Anti-Blackness When Black People Are Killed by the Police, 'Racism' Isn't the Right Word." New York Times, June 4.

Smith, Watts C., and Sarah Mayorga-Gallo. 2017. "The New Principle-policy Gap: How Diversity Ideology Subverts Diversity Initiatives." Sociological Perspectives 60, no. 5: 889-911.

Sutton, John R., Frank Dobbin, John W. Meyer, and W. Richard Scott. 1994. "Legalization of the Workplace." American Journal of Sociology 99, no. 4: 944-71.

Wilkins, David B. 2004. "From 'Separate Is Inherently Unequal' to 'Diversity Is Good for Business': The Rise of Market-Based Diversity Arguments and the Fate of the Black Corporate Bar." Harvard Law Review 117, no. 5: 1548-61. 